\title{
Penelitian dan Pengabdian Masyarakat pada Perguruan Tinggi
}

\author{
Idris HM Noor \\ Peneliti pada Puslitjaknov Balitbang Kemdiknas. Email: idrs_noor@yahoo.com
}

\begin{abstract}
Abstrak: Tujuan penelitian adalah untuk mengetahui implementasi kebijakan dan pelaksanaan program penelitian dan pengabdian masyarakat pada perguruan tinggi (PT). Metode penelitian adalah metode campuran kuantitatif dan kualitatif dengan teknik analisis deskriptif. Sampel penelitian berjumlah 160 responden yang diambil secara purposive yaitu ketua/anggota lembaga penelitian dan pengabdian masyarakat di perguruan tinggi Negeri (PTN) dan perguruan tinggi Swasta (PTS). Penelitian dilaksanakan selama 7 bulan mulai bulan April sampai bulan Oktober 2008 di 6 provinsi yaitu provinsi Nusa Tenggara Barat (NTB), provinsi Bali, provinsi Daerah Khusus Yogyakarta (DIY), provinsi Jawa Barat, provinsi Sumatera Barat, dan provinsi Sumatera Utara. Alat dan teknik pengumpulan data adalah pedoman studi dokumentasi, kuesioner, wawancara, dan focus group discussion (FGD). Data primer adalah nara sumber di PT, sedangkan data sekunder adalah dokumen mengenai peraturan perundang-undangan dan penelitianpenelitian terkait sebelumnya. Hasil penelitian adalah: 1) kebijakan program penelitian dan pengabdian masyarakat di PT berdasarkan kebijakan umum Direktorat Pendidikan Tinggi, Depdiknas; 2) implementasi kebijakan dalam meningkatkan kualitas pendidikan tinggi masih ada kendala antara lain lembaga penelitian dan pengabdian masyarakat masih terpisah, sosialisasi P2M masih kurang, dan kemampuan metodologi penelitian dosen masih rendah' 3) hasil-hasil penelitian yang dilaksanakan oleh PTN/PTS dapat dimanfaatkan untuk pengembangan dan peningkatan ilmu pengetahuan. Namun masih sedikit yang dapat dimanfaatkan untuk meningkatkan jumlah materi ajar, publikasi nasional/internasional, dan perolehan hak paten; dan 4) kegiatan pengabdian masyarakat belum berdasarkan hasil penelitian.
\end{abstract}

Kata kunci: Penelitian, pengabdian masyarakat, analisis kebijakan, ilmu pengetahuan, materi ajar

\begin{abstract}
The objectives of the research is to know the implementation of policy and implementation of the research program and the public service at Higher Education (HE). The research method is the mixed of quantitative and qualitative methods with a descriptive analysis. Sample of the research is 160 repondents taken purposively of head and members of the research and public service institutions at public and private of HE. The research was conducted for 7 months from April to October 2008 at six provinces: West Nusa Tenggara province, Bali province, Special Yogyakarta province, West Java province, West Sumatera province, and South Sumatera province. Tools and the techniques of data collecting are using documentation study, questionnaires, inteview, and focus group discussion. Primary data is the information from the resource persons from HE while the secondary data is taken from the documents about the rules as well as the laws and the related research done by other people. The findings of the research are: 1) the policy of research program and the public service at $\mathrm{HE}$ is based on the general policy of the HE Directorate, Ministry of National Education; 2) the implementation of policy in improving quality of HE still has constraints such as the institutions of research and public service are still separate, the socialization of programs of public service is still low, and most lecturers at HE are stil lack of having research methodolgy; 3 ) the research findings of both public and private HE can be implemented to develop and improve science. However, there has a few of the research findings that can be used for improving teaching and learning materials for higher education, very few of national as well international publications, and very few of having patent rights; and 4) the activities in public service are not based on the findings of the research yet.
\end{abstract}

Key words: research, public service, policy analysis, science, learning materials 


\section{Pendahuluan}

Pendidikan merupakan salah satu investasi yang sangat penting untuk menyiapkan sumber daya manusia (SDM) khususnya dalam pesaingan di era global saat ini. Melalui pendidikan, bangsa Indonesia akan mampu merencanakan dan menyiapkan tenaga terdidik yang mempunyai kemampuan bersaing dengan negara lain. Disamping itu, disadari bahwa perguruan tinggi (PT) merupakan lembaga pendidikan yang sangat berperan dalam mengembangkan sumber daya manusia (SDM) yang bermutu guna memenuhi kebutuhan pembangunan. Mutu perguruan tinggi yang merata dan sesuai dengan kebutuhan wilayah menjadi hal yang penting dalam pembangunan daerah, terutama di era otonomi daerah. Oleh karena itu, program di PT harus dilihat keuntungan dan masa depan mahasiswa.

Sehungungan dengan itu, pemerintah menetapkan tiga pilar kebijakan pendidikan melalui Undang-Undang Nomor 20 Tahun 2003 tentang Sistem Pendidikan Nasional (UUSPN2003), Peraturan Presiden No. 7 Tahun 2005 tentang Rencana Pembangunan Jangka Menengah (2005-2009) bidang pendidikan serta peraturan perundang undangan yang mendukungnya. Untuk melaksanakan peraturan dan undang-undang tersebut, Depdiknas telah menetapkan Renstra tahun 2005-2009 yang memuat program yang berkaitan dengan program strategis penelitian dan pengembangan pendidikan. Program tersebut mengacu pada pilar pemerataan dan perluasan akses serta peningkatan mutu, relevansi, dan daya saing perguruan tinggi. Tujuanya ialah, Pertama, meningkatkan pemerataan dan perluasan akses bagi semua warga melalui program-program pendidikan diploma, sarjana, magister, spesialis, dan doktor. Kedua, meningkatkan mutu, relevansi, dan daya saing pendidikan tinggi dalam rangka menjawab kebutuhan pasar kerja, serta pengembangan iptek, untuk memberikan sumbangan secara optimal bagi peningkatan kesejahteraan masyarakat dan daya saing bangsa.

Berkaitan dengan program pemerintah tersebut, maka perlu dilakukan penelitian untuk mengetahui informasi mengenai program pengabdian masyarakat yang dilaksanakan berdasarkan hasil penelitian.
Masalah penelitian ini ialah 1) bagaimana kebijakan program penelitian dan pengabdian masyarakat yang dilakukan oleh perguruan tinggi (PT) baik perguruan tinggi negeri maupun swasta; 2) bagaimana implementasi kebijakan penelitian dan pengabdian masyarakat yang dilaksanakan oleh PT negeri dan swasta selama ini dalam meningkatkan kualitas pendidikan tinggi; 3 ) bagaimana pemanfaatan hasil-hasil penelitian dan pengembangan yang dilakukan oleh PT untuk peningkatan keilmuan dan/atau ilmu pengetahuan dan teknologi terutama dalam kegiatan perekayasaan, inovasi serta difusi teknologi; dan 4) bagaimana pelaksanaan pengabdian masyarakat yang berkaitan dengan pemanfaatan hasil-hasil penelitian yang dilakukan oleh PT selama ini.

Tujuan penelitian ini yaitu untuk mendapatkan informasi mengenai 1) kebijakan program penelitian dan pengabdian masyarakat yang dilakukan oleh perguruan tinggi (PT) baik perguruan tinggi negeri maupun swasta; 2) implementasi kebijakan penelitian dan pengabdian masyarakat yang dilaksanakan oleh PT negeri dan swasta selama ini dalam meningkatkan kualitas pendidikan tinggi; 3 ) pemanfaatan hasil-hasil penelitian dan pengembangan yang dilakukan oleh PT untuk peningkatan keilmuan dan/atau ilmu pengetahuan dan teknologi terutama dalam kegiatan perekayasaan, inovasi serta difusi teknologi; dan 4) pelaksanaan pengabdian masyarakat yang berkaitan dengan pemanfaatan hasil-hasil penelitian yang dilakukan oleh PT selama ini. Ruang lingkup penelitian ini adalah kegiatan penelitian dan pengabdian masyarakat di perguruan Tinggi (BHMN, PTN dan PTS).

\section{Kajian Literatur}

\section{Penelitian}

Pengertian penelitian (research) dalam dunia pendidikan tinggi adalah kegiatan mencari kebenaran (to seek the truth) yang dilakukan menurut kaidah dan metode ilmiah (scientific research) secara sistematis untuk memperoleh informasi, data, dan keterangan yang berkaitan dengan pemahaman dan pembuktian kebenaran atau ketidakbenaran suatu asumsi dan/atau hipotesis di bidang ilmu pengetahuan dan 
teknologi serta menarik kesimpulan ilmiah bagi keperluan kemajuan ilmu pengetahuan dan teknologi. Pengertian penelitian didefinisikan juga oleh Howard and Sharp (1993 dalam Bell (1993:2) mengatakan: research as seeking through methodological process to add to one's own body of knowledge and hopefully, to that of others, by the discovery of non-trivial facts and insights. Selanjutnya Drew (1980) dalam Bell (1993:2) yang mengatakan bahwa research is conducted to solve problems and to expand knowledge and he stresses that research is a systematic way of asking questions, a systematic method of enquiry. Dengan demikian, penelitian harus dikerjakan menurut kaidah dan metode ilmiah/keilmuan (scientific research) secara obyektif, logis dan sistematis. Selain penelitian dalam suatu disiplin ilmu tertentu, penelitian juga dapat dilakukan dengan melibatkan berbagai ilmu atau inter-disiplin.

Hasil penelitian, pengembangan, dan/atau ilmu pengetahuan dan teknologi harus dapat dimanfaatkan dalam kegiatan perekayasaan, inovasi, dan difusi teknologi. Oleh karena itu, PT harus meningkatkan mutu kegiatan penelitian melalui peningkatan profesionalisme penelitipenelitinya. Yang dimaksud dengan profesionalisme di sini ialah menjadikan penelitian sebagai profesi utama, purna waktu dengan imbalan yang pantas bagi para peneliti. Selain peneliti sebagai individu, juga diperlukan peneliti sebagai suatu kelompok atau tim yang bekerja bersama.

Penelitian dapat dikategorikan berdasarkan kegiatannya yaitu: 1) penelitian dasar atau fundamental merupakan penelitian ilmu dasar yang sangat berkaitan dengan pengembangan teori dan yang mendasari kemajuan ilmu pengetahuan tertentu, 2) penelitian terapan merupakan kegiatan penelitian untuk menerapkan ilmu dasar agar dapat menghasilkan produk teknologi yang kelak bermanfaat bagi kesejahteraan masyarakat, 3) penelitian pengembangan merupakan kegiatan penelitian pengembangan teknologi atas permintaan masyarakat untuk meningkatkan produk yang telah ada agar dapat memenuhi kebutuhan mereka.

Lingkup penelitian dapat dikelompokkan menjadi dua yaitu 1) penelitian yang yang terkait langsung dengan kegiatan pendidikan misalnya; penelitian untuk menghasilkan skripsi, tesis, dan disertasi atau penelitian yang dipakai untuk meningkatkan kualitas mengajar, dan 2) penelitian yang dilakukan untuk tujuan pengembangan teori dan ilmu pengetahuan, atau untuk tujuan pelayanan dan pengabdian pada publik. Kedua lingkup penelitian ini saling terkait dan saling menopang serta dapat melibatkan semua staf akademik PT beserta mahasiswanya dan juga berbagai pihak luar yang berkepentingan.

Untuk dapat menerapkan hasil-hasil penelitian dalam kegiatan pengabdian masyarakat, diperlukan kebijakan yang tepat dan terarah. Sehubungan dengan itu, berikut sekilas diuraikan teori yang berkaitan dengan penelitian kebijakan.

\section{Penelitian Kebijakan (Policy Research)}

Pada prinsipnya, penelitian kebijakan merupakan sebuah penelitian yang bertujuan untuk memberikan saran atau masukan kepada penentu kebijakan seperti politisi atau birokrat dalam menentukan kebijakan. Dalam bidang pendidikan, penelitian kebijakan adalah sebuah penelitian yang dilakukan berdasarkan kriteria penelitian secara ilmiah. Majchrzak (1984) dalam Danim (2005:23) mendefinisikan bahwa penelitian kebijakan sebagai sebuah proses penyelenggaraan penelitian untuk mendukung kebijakan atau analisis terhadap masalah-masalah sosial yang bersifat fundamental secara teratur untuk membantu pengambil kebijakan memecahkan masalah dengan jalan menyediakan rekomendasi yang berorientasi kepada tingkah laku pragmatik. Majchrzak (1984:15-18) mengatakan ada empat jenis penelitian kebijakan 1) kebijakan penelitian bervariasi tergantung dari sumber biaya pengguna penelitian itu, 2) kebijakan penelitian bervariasi terhadap fokus pemecahan masalah. Ini berarti semua masalah sosial didefinisikan dengan tepat untuk menentukan sebuah penelitian dan solusinya, 3) kebijakan penelitian bervariasi tergantung dari organisasi, dan 4) kebijakan penelitian bervariasi tergantung pada disiplin ilmu peneliti. Agar disebut ilmiah, penelitian kebijakan harus memenuhi kriteria, antara lain ada terminologinya, berdasarkan bukti-bukti empirik, bebas dari nilai individual, sistimatika kerjanya jelas, menggunakan prinsip-prinsip analisis, ada 
hipotesis yang diuji, menggunakan ukuran yang obyektif, dan menggunakan teknik-teknik kuantifikasi (Danim 2005: 7-8).

Manajemen penelitian adalah pengaturan yang tepat mengenai sesuatu yang harus dilakukan dalam penelitian mulai dari perencanaan penelitian, penentuan populasi dan sampel penelitian, siapa yang akan menggunakan hasil penelitian, dan apa yang direkomendasikan dalam penelitian sesuai dengan hasil penelitian. Griffin (1987:8). Sementara itu, Mondy dan Premeaux (1993:5) mengatakan bahwa manajemen adalah proses meerencanakan dan mengambil keputusan, mengatur, memimpin, dan mengontrol dan mengorganisir manusia, biaya, fisik, dan sumber informasi untuk mencapai tujuan organisasi secara efektif dan efisien.

Dalam menentukan kebijakan penelitian, ada berbagai dimensi yang berbeda dan tidak perlu melakukan koordinasi semua kebijakan penelitian secara menyeluruh sebagai sebuah obyek dari keseluruhan sistem. Koordinasi hanya dimaksudkan untuk menghindari duplikasi, membuat perbandingan yang berkaitan dengan pertanyaan khusus, dan berguna bagi penelitian khusus (http://www.fao.org/Wairdocs/ TAC/ X5792E/x5792e09.htm). Dalam mengambil kebijakan penelitian, peneliti dan penyandang dana penelitian baik dari organisasi pemerintah maupun lembaga swasta dan lembaga-lembaga lain atau individu, biasanya sama-sama membahas masalah penelitian, dan tujuan yang akan dicapai untuk memecahkan persoalan yang dihadapi oleh pengguna hasil penelitian. Namun, disadari pula bahwa tidak semua unsur yang terkait dengan penelitian melakukan prosedur yang tepat. Banyak diantara pengambil kebijakan penelitian dan peneliti kadang-kadang tidak mempunyai kesempatan, tidak mengikuti prosedur yang ditetapkan, dan tidak banyak mempunyai waktu dan kesempatan untuk membicarakan langkahlangkah yang harus diikuti dalam kegiatan penelitian sampai pada pengambilan keputusan.

\section{Analisis Kebijakan}

Definisi Kebijakan

Banyak ahli memberikan definisi kebijakan. Kebijakan menurut Derbyshire dalam Wibawa (1994:49) ialah a set of planned activities aimed at improving social and economical conditions. Definisi ini sangat umum, hanya mengaitkanya dengan keadaan sosial dan ekonomi. Namun, dapat dikatakan bahwa kebijakan merupakan usaha atau tindakan untuk memperbaiki situasi sosial dan ekonomi. Sedangkan Hofferbert dalam Wibawa (1994:49) mendefinisikan kebijakan "any decision taken by certain decision makers for public goals". Dia menekankan bahwa tindakan yang diambil dalam menetapkan keputusan itu sejajar. Lain halnya dengan Dunn (1981) dalam Dwidjowijoto (2006:x) yang mendefinisikan kebijakan "policy as complex pattern of independent collective choices, including decision not to act, made by government bodies and officials". Dari ketiga definisi kebijakan tersebut dapat dikatakan bahwa secara umum kebijakan merupakan tindakan yang diambil untuk menentukan sesuatu yang akan dilakukan sebagai dasar kegiatan yang akan dilaksanakan.

Proses dan Produk Penelitian Kebijakan

Proses penelitian kebijakan dalam banyak hal sama dengan kerja penelitian- penelitian tradisional, namun sesungguhnya tidak identik. Dalam hal tertentu, proses dan produk penelitian kebijakan berbeda dengan penelitian tradisional. Danim (2005:163) mengatakan bahwa dalam penelitian kebijakan, ada beberapa hal yang perlu diperhatikan, antara lain a) penelitian kebijakan punya keterlibatan ilmiah yang rendah, b) penelitian kebijakan memerlukan acuan teoretis, meskipun bukan merupakan predetermined theory; c) penelitian kebijakan yang diselenggarakan oleh peneliti kebijakan mensyaratkan keterlibatan intensif para stakeholder atau study user. d) penelitian kebijakan umumnya dilakukan atas dasar permintaan klien, e) penelitian mensyaratkan variabel lunak yang bersifat multifaset dan multidimensional, f) penelitian kebijakan sangat prihatin dengan kekuatan sosio-politik serta lingkungan, dan g) penelitian kebijakan selalu diakhiri dengan rekomendasi untuk keperluan pengambilan kebijakan dalam rangka memecahkan masalah sosial.

Dalam penelitian kebijakan, stakeholder mempunyai peranan yang penting dalam menentukan kebijakan apa yang harus diambil. Kepentingan pribadi, kelompok, atau kepetingan 
politik menjadi faktor yang mempengaruhi penentu kebijakan dalam mengambil keputusan. Dari semua hasil penelitian yang disampaikan atau disarankan oleh peneliti belum tentu semuanya digunakan oleh penentu kebijakan. Hal ini dapat dipahami karena dalam pengambilan keputusan kebijakan, faktor internal dan eksternal penentu kebijakan juga ikut ambil bagian dalam menentukan kebijakan.

Untuk mendapatkan gambaran tentang analisis kebijakan, berikut diuraikan secara singkat pandangan dan pendapat para ahli analisis kebijakan sebagai berikut:

Analisis kebijakan menurut Dunn (1999) dalam Dwidjowijoto (2006:7) adalah aktivitas intelektual dan praktis yang ditujukan untuk menciptakan secara kritis, menilai dan mengkomunikasikan pengetahuan tentang proses kebijakan. Analisis kebijakan adalah suatu aktivitas intelektual yang dilakukan dalam proses politik tapi tidak dimaksudkan mengganti politik dan membangun elit teknokratis. Sedangkan William dalam Dwidjowijoto (2006:36) mendefinisikan kebijakan sebagai sebuah cara menyintesikan informasi termasuk hasil-hasil penelitian untuk menghasilkan format keputusan kebijakan yang ditentukan dari sejumlah alternatif pilihan dan menentukan informasi yang relevan dengan kebijakan (policy analysis is a means of syntesizing information including research results to produce a format for policy decisions and determining future needs for policy relevant information). Sedangkan Weimer dan Vining (1999) dalam Dwidjowijoto (2006:36) mendefinisikanya sebagai saran yang berorientasi pada klien yang berkaitan dengan keputusan publik dan memuat nilai-nilai sosial (Policy analysis is a client oriented advice relevant to public decision and informed by social values). Weimer dan Vining (1999) dalam Dwidjowijoto (2006:36) memahami analisis kebijakan sebagai sebuah kegiatan yang mengandung tiga nilai yaitu pragmatis (client oriented), mengacu pada keputusan (kebijakan), dan tujuannya melebihi kepentingan atau nilai-nilai klien.

Weimer dan Vining (1999) dalam Dwidjowijoto (2006:57) menyarankan tiga skenario yaitu; 1 ) menulis skenario yang mengacu pada policy outcomes; 2) mengeritik skenario dari berbagai perspektif kepentingan dan karakter perilaku, dan
3) melakukan revisi skenario sehingga menjadi lebih masuk akal.

Selanjutnya, Patton dan Savicky (1993:482) dalam Dwidjowijoto (2006:59) mengatakan " policy analyst are often required to give advice to policy maker in incredibly short periods of time, in contrast to university researcher and think tank consultant who are hired specifically to conduct intensive research on public policy issues". Edward S. Quade (1982) dalam Dwidjowijoto (2006:101) mengatakan bahwa tujuan analisis untuk memperbaiki keputusan kebijakan karena kebijakan sebelumnya tidak memuaskan publik.

Dari definisi-definisi tersebut di atas dapat dikatakan bahwa analisis kebijakan merupakan sebuah cara dalam menetapkan keputusan yang berdasarkan beberapa alternatif baik hasil penelitian, pengetahuan, atau dari proses politik sehingga mampu memberikan informasi kebijakan yang tepat.

\section{Pengabdian pada Masyarakat}

Program pengabdian pada masyarakat yang dilaksanakan oleh perguruan tinggi (PT) adalah salah satu dari implementasi Tridharma PT. Program ini dilaksanakan dalam berbagai bentuk misalnya; pendidikan dan pelatihan masyarakat, pelayanan masyarakat, dan kaji tindak dari Iptek yang dihasilkan oleh PT. Tujuan program ini adalah menerapkan hasil-hasil Iptek untuk pemberdayaan masyarakat sehingga menghasilkan perubahan pengetahuan, keterampilan, dan sikap dari kelompok masyarakat sasaran.

Ada berbagai jenis program kegiatan pengabdian pada masyarakat yang dilaksanakan oleh PT berdasarkan program Direktorat Jenderal Pendidikan Tinggi Depdiknas (2004), yaitu 1) Program Vucer adalah salah satu kegiatan pengabdian kepada masyarakat dalam bentuk penerapan dan pengembangan hasil penelitian oleh PT. Program ini memberikan prioritas pada teknologi maupun manajemen termasuk pembukuan dan pemasaran, 2) Program Vucer Multi Tahun (VMT) merupakan salah satu kegiatan pengabdian kepada masyarakat dalam bentuk penerapan dan pengembangan hasil penelitian oleh PT yang dapat berlangsung selama tiga tahun karena komoditas yang dihasilkan harus dapat diekspor atau dijual antar pulau, 3) Unit 
Usaha Jasa dan Industri (u-UJI) adalah program PT dalam era knowledge based economy untuk mendukung upaya pengembangan otonomi PT menjadi Badan Hukum Milik Negara, dan 4) Potensi Masyarakat Sinergi Pemberdayaan merupakan realisasi dari kebijakan pemerintah tentang otonomi daerah dan upaya peningkatan sinergi pemberdayaan masyarakat yang memerlukan strategi integratif berbagai pihak. Program Sinergi Pemberdayaan Potensi Masyarakat (Sibermas) dilatarbelakangi pula berbagai permasalahan yang eksis di masyarakat, antara lain; a) ketidakberdayaan sebagian besar masyarakat terhadap pembangunan kehidupan pribadi, keluarga, dan masyarakat dalam menyongsong era globalisasi; b) Ipteks perguruan tinggi belum secara sengaja ditujukan bagi kesejahteraan masyarakat; dan c) potensi masyarakat maupun sumber daya alam lingkungannya belum termanfaatkan dengan baik dan arif. Disamping itu, program pengabdian kepada masyarakat yang selama ini telah dilaksanakan memerlukan program besar yang mampu memayunginya sehingga sinergisme antar program dapat terwujud (DP2M Ditjen Dikti, 2008).

\section{Metode Penelitian}

Metode penelitian yang digunakan adalah metode campuran kuantitatif dan kualitatif dengan teknik analisis deskriptif.

Penelitian ini dilaksanakan pada tahun 2008 selama 7 bulan mulai bulan April sampai bulan Oktober 2008. Populasi penelitian adalah semua pejabat/dan mantan pejabat, serta ketua/ anggota lembaga penelitian dan pengabdian masyarakat di perguruan tinggi (PT) di provinsi Daerah Khusus Yogyakarta (DIY), provinsi Jawa Barat, provinsi Nusa Tenggara Barat (NTB), provinsi Bali, provinsi Sumatera Barat, dan provinsi Sumatera Utara. Sample penelitian diambil secara purposive yaitu 160 responden yang terdiri atas pejabat dan mantan pejabat serta ketua dan anggota lembaga penelitian dan pengabdian masyarakat di PT negeri dan swasta. Selain data yang diperoleh dari responden tersebut, data juga diambil dari dokumen mengenai peraturan perundang-undangan dan penelitian-penelitian terkait sebelumnya. Alat dan teknik pengumpulan data adalah pedoman studi dokumentasi kuesioner, wawancara, dan focus group discussion (FGD).
Analisis data menggunakan teknik deskriptif kuantitatif (prosentase) dan kualitatif. Data dianalisis dengan teknik kuantitatif yaitu memprosentasekan jawaban nara sumber (responden). Hal ini dilakukan untuk mengetahui berapa banyak nara sumber yang menjawab pertanyaan atau yang memberi pernyataan dalam setiap butir instrumen yang ditanyakan. Teknik memprosentasekan jawaban nara sumber seperti ini boleh digunakan seperti yang dikatakan oleh Arikunto (2000:352) bahwa data prosentase (yang dinyatakan dalam bilangan merupakan ukuran kuantitatif) dan hanya merupakan langkah awal dari keseluruhan penelitian. Selanjutnya, data yang telah diprosentasekan tersebut dikualitatifkan dan dinyatakan dalam sebuah predikat yang menunjukkan pernyataan keadaan ukuran kualitas dalam bentuk paling besar, sedang, kecil atau paling baik, baik, kurang baik, tidak puas, kurang memuaskan, memuaskan, dan sangat memuaskan. Data yang sudah dikualitatifkan tersebut dibahas secara sistematis yaitu dengan cara menguraikan, mensintesis, membandingkan, mengkombinasikan dengan hasil penelitian orang lain, membandingkan dengan teori dan memberikan komentar atau argumentasi (Emzir dkk. 1995:18-19). Proses analisis, penilaian, dan pengecekan data dilakukan selama penelitian berlangsung dan dilakukan berulang kali. Prosedur tersebut dilakukan agar data yang dianalisis tersebut bisa mendekati kebenaran sesuai dengan prosedur analisis data kualitatif seperti yang dianjurkan oleh Strauss dan Corbin (1990:62) yang menekankan pentingnya membandingkan dan menanyakan beberapa pertanyaan yang berkaitan dengan data tersebut. Hal ini juga ditegaskan oleh Moleong (2000: 6-7) bahwa penelitian kualitatif lebih mementingkan proses dari pada hasil. Oleh karena itu, data tersebut dapat dibandingkan dengan catatan lapangan dan dokumen resmi atau dokumen pribadi.

\section{Hasil Penelitian dan Pembahasan}

Hasil penelitian dapat dikemukakan sebagai berikut:

Kebijakan program penelitian dan pengabdian masyarakat yang dilakukan oleh perguruan tinggi baik perguruan tinggi (PT) negeri maupun swasta 
Kebijakan program penelitian dan pengabdian masyarakat yang dilakukan oleh perguruan tinggi (PT) negeri dan swasta berdasarkan kebijakan umum yang ditetapkan oleh Direktorat Pendidikan Tinggi (Dikti) Depdiknas. Secara umum, kebijakan program penelitian dan pengabdian pada masyarakat tersebut sebagian besar dapat dilaksanakan oleh PT seperti yang dikemukakan oleh mayoritas (84.34\%) responden. Namun, sebagian responden mengatakan tidak dapat menerapkan kebijakan tersebut karena belum ada standar mutu penelitian sebagai dasar pelaksanaan, sosialisasi pelaksanaan program masih kurang dan belum ada payung penelitian.

Kebijakan penelitian PT memprioritaskan pilar peningkatan mutu, relevansi, dan daya saing pendidikan diungkapkan oleh sebagian $(46.46 \%)$ responden. Selanjutnya, dasar dalam menentukan kegiatan penelitian di PT adalah 1) profesionalisme para penelitinya, 2) kaidah dan metode ilmiah/keilmuan (scientific research) secara obyektif, logis, dan sistematis, 3) etika penelitian sesuai dengan Ethical Peer Reviewer, dan 4) visi, misi (Renstra) PT.

Dari kebijakan tersebut diperoleh informasi bahwa 24.39\% responden mengatakan Visi, Misi (Renstra) PT, dan $30.89 \%$ responden mengatakan semua aspek di atas. Sementara dalam menentukan kegiatan pengabdian masyarakat terungkap bahwa mayoritas $(52.38 \%)$ responden mengatakan berdasarkan masalah yang dihadapi oleh PT, sesuai dengan Renstra Depdiknas, usulan stakeholders, dan kebutuhan masyarakat. Dalam kebijakan pelaksanaan pengabdian pada masyarakat di PT ditemukan bahwa hampir semua (92.54\%) responden mengatakan harus berdasarkan pada hasil penelitian atau merupakan aplikasi/hasil penelitian.

Implementasi kebijakan penelitian dan pengabdian masyarakat yang dilaksanakan oleh PT negeri dan swasta selama ini dalam meningkatkan kualitas pendidikan tinggi

Implementasi kebijakan penelitian yang dilaksanakan oleh PT berdasarkan kebijakan umum penelitian yang ditetapkan oleh Direktorat Pendidikan Tinggi (Dikti) Depdiknas. Disamping itu, PT juga menetapkan kebijakan sendiri terutama lembaga/individu pelaksana penelitian, yaitu dilaksanakan oleh lembaga penelitian, departemen/jurusan/prodi, dosen secara individu atau kelompok seperti yang dikatakan oleh sebagian $(27.62 \%)$ responden. Disamping itu, lembaga lain yang mendapat tugas khusus dalam rangka penelitian dan aplikasi hasil riset adalah inkubator bisnis. Selanjutnya, dalam perencanaan penelitian jangka menengah dan jangka panjang, PT (Pusat, Departemen, Prodi) atau individu dosen sudah mempunyai "Road Map" penelitian dikatakan oleh (50\%) responden, sedangkan sistem jaminan mutu (quality assurance) internal untuk kegiatan penelitian di PT tidak ada seperti yang dikatakan oleh sebagian besar (53.05\%) responden.

Sementara itu, dalam meningkatkan kualitas pengabdian pada masyarakat, PT mempunyai cara, antara lain 1) melaksanakan studi kelayakan, 2) menerapkan hasil penelitian, 3) menambah dana pengabdian pada masyarakat, 4) pengembangan metodologi Participaty Active Reseacrh (PAR), 5) relevansi penelitian dan kebutuhan masyarakat, 6) meningkatkan IPTEK bagi masyarakat, 7) membuat penelitian terapan dan penelitian tepat guna, dan 8) minat masyarakat terhadap iptek.

Selanjutnya, pelaksanaan kebijakan yang ditetapkan PT tidak menghadapi kendala yang berarti seperti yang dikemukakan oleh sebagian besar $(54.05 \%)$ responden. Namun, sebagian (45.95\%) responden mengatakan ada kendala, karena 1) antara lembaga penelitian dan lembaga pengabdian masyarakat terpisah, 2) sosialisasi program penelitian berjalan dengan baik namun sosialisasi P2M dirasakan kurang, dan 3) kemampuan metodologi peneliti masih rendah.

Khususnya mengenai pelaksanaan penelitian, kendala yang dihadapi menurut sebagian besar $(53.19 \%)$ responden adalah kurangnya biaya dan masih kurangnya minat dosen untuk mengusulkan proposal kegiatan pengabdian masyarakat untuk program-program multi tahun seperti UJI, Sibermas\&Vucer Multi Tahun, dan kurangnya ideide baru dari dosen yang dibutuhkan oleh masyarakat. Selain dana dari Dikti, masing-masing PT menyediakan dana penelitian sendiri untuk mengembangkan penelitian prioritas/unggulan dalam meningkatkan keterampilan dosen diungkapkan oleh sebagian besar (68.35\%) responden. Selanjutnya, untuk membantu 
pemerintah daerah/pusat, PT memberikan saran kebijakan sesuai dengan hasil penelitian, mengadakan seminar, simposium, lokakarya, pelatihan tentang hasil penelitian, dan menyebarluaskan informasi mengenai hasil penelitian, sedangkan untuk meningkatkan mutu pengabdian pada masyarakat, PT bekerja sama dengan masyarakat diungkapkan oleh semua (97.26\%) responden.

Pemanfaatan hasil-hasil penelitian dan pengembangan yang dilakukan oleh PT untuk peningkatan keilmuan dan/atau ilmu pengetahuan dan teknologi terutama dalam kegiatan perekayasaan, inovasi serta difusi teknologi

Hasil-hasil penelitian yang dilaksanakan oleh PIN PTS dapat dimanfaatkan untuk pengembangan dan peningkatan ilmu pengetahuan serta kemampuan dosen dikatakan oleh sebagian besar $(56.96 \%)$ responden. Sebagian (26.2\%) responden mengatakan tidak dapat dimanfaatkan karena penerapan hasil penelitian memerlukan dukungan berbagai unsur politik, ekonomi, dan sosial. Sementara hasil penelitian dalam meningkatkan jumlah buku ajar dan publikasi penelitian di jurnal (nasional, internasional), mempercepat perolehan hak paten dan meningkatkan kemampuan masyarakat masih sangat kurang.

Pelaksanaan pengabdian masyarakat yang berkaitan dengan pemanfaatan hasil-hasil penelitian yang dilakukan oleh PT

Bentuk kegiatan pengabdian kepada masyarakat yang dilaksanakan oleh perguruan tinggi (PT) adalah pendidikan dan pelatihan masyarakat, pelayanan masyarakat, dan kaji tindak dari ipteks yang dihasilkanya.

Manfaat program pengabdian masyarakat bagi pelaksanaan pendidikan di PT adalah 1) untuk pengembangan kelembagaan dan mutu pendidikan, 2) mahasiswa mampu mengidentifikasi serta memberi solusi suatu masalah sebagai dasar analisis dalam menyikapi fenomena masyarakat, 3) melatih calon sarjana untuk terjun di masyarakat, dan 4) mengembangkan IPTEK. Selain program tersebut di atas, ditemukan bahwa kegiatan pengabdian masyarakat yang dilaksanakan oleh PTN/PTS tidak berdasarkan hasil penelitian seperti yang dikemukakan oleh sebagian besar $(81.43 \%)$ responden karena: 1 ) belum ada standar mutu penelitian sebagai dasar pelaksanaan, 2) sosialisasi pelaksanaan program masih kurang, 3) belum ada payung penelitian, 4) biaya yang tersedia masih kurang. Disamping itu, ada kendala lain seperti yang dikatakan oleh $84.81 \%$ responden, yaitu 1 ) belum semua hasil penelitian menjadi kebutuhan masyarakat, 2) masih banyak hasil penelitian yang belum tuntas diselesaikan dan perlu waktu, 3) biaya, sarana/ pelaksana, 4) kemampuan masyarakat dalam menerapkan hasil penelitian sangat kurang, 5) hasil penelitian belum memberikan solusi yang jelas mengenai masalah yang dihadapi masyarakat, 6) dosen terlalu banyak mengajar sehingga kurang berkesempatan meneliti dan mengabdi, 7) kultur masyarakat yang homogen, 8) kurang siapnya Pemda menerima PT, 9) kebijakan pemerintah pusat dan pemerintah daerah tidak sinkron, 10) ada kalanya hasil penelitian jika diterapkan pada pengabdian membutuhkan peralatan yang cukup mahal harganya, 11) kurangnya dana pengabdian pada masyarakat 12) hasil penelitian masih bersifat sangat mendasar, 13) hasil penelitian ilmu murni/ dosen lebih sulit diterapkan langsung daripada hasil penelitian bidang ilmu terapan sehingga hasil penelitian yang dilakukan tidak mampu memberikan solusi.

Hal-hal yang perlu dipertimbangkan dalam menetapkan kegiatan pengabdian pada masyarakat di PT terungkap 52.38\% responden mengatakan berdasarkan masalah yang dihadapi oleh PT, sesuai dengan Renstra Depdiknas, usulan stakeholders, dan kebutuhan masyarakat. Disamping itu, aspek yang perlu diperhatikan agar hasil kegiatan pengabdian pada masyarakat maksimal dan berkualitas harus memperhatikan kebutuhan lingkungan dan tempat pelaksanaan kegiatan, potensi sumber daya, infrastruktur, sarana/prasarana yang tersedia, usulan stakeholders, kebutuhan mahasiswa, dan kebutuhan PT seperti yang dikatakan oleh sebagian besar $(48.35 \%)$ responden.

Hasil-hasil penelitian yang telah dimanfaatkan dalam kegiatan pengabdian pada masyarakat sejak dua tahun terakhir antara lain 1) penyulingan minyak dari kulit manis, 2) peningkatan mutu biji Cacao melalui bistek, 3) 
masalah organisasi keagamaan, 4) kehidupan umat beragama, 5) pemberdayaan madrasah, 6) pemberdayaan masyarakat adat, 7) perbaikan teknologi peralatan dalam bidang pengolahan pertanian \& pasca panen, 8) peningkatan produksi pertanian dan peternakan, 9) peningkatan kesehatan masyarakat, 10) perluasan akses \& peningkatan mutu pendidikan di sekolah dan madrasah, 11) pelatihan teknologi tepat guna, 12) implementasi kebijakan dalam peningkatan mutu pembelajaran berdasarkan KTSP, 13) pemetaan potensi keagamaan masyarakat, 14) klasifikasi masyarakat (prasejahtera, sejahtera I dan seterusnya), 15) pembuatan penangkaran kentang, dan 16) pembuatan penangkaran padi.

Bentuk kerjasama antar lembaga penelitian dan pengabdian pada masyarakat yang telah dilaksanakan PT terungkap selama ini baru pada taraf tukar informasi seperti yang dikatakan oleh $42.86 \%$ responden. Disamping itu, $33.33 \%$ responden mengatakan dengan cara mengikutsertakan dosen dan mahasiswa dalam pertukaran peneliti antar lembaga.

Selain untuk meningkatkan hasil penelitian untuk pengabdian masyarakat, peningkatan pemanfaatan hasil penelitian untuk kebijakan diperlukan koordinasi dengan stakeholders/ penentu kebijakan misalnya Pemda, Dikti, dan Kementerian Riset dan Teknologi 1) agar manfaatnya dapat dilihat secara nyata, 4) untuk menentukan arah \& kebijakan penelitian, 5) dapat digunakan untuk masukan dalam pengembangan program, dan 6) dapat dijadikan dasar dalam mentukan kebjiakan pembanguan tahun berikutnya. Sedangkan mereka yang mengatakan tidak berkoordinasi adalah kebanyakan penelitian yang dilaksanakan hanya untuk pengembangan ilmu pengetahuan dan untuk kepentingan administratif dosen peneliti yang bersangkutan. Demikian halnya, Dikti perlu meningkatkan kerjasama dengan PT dan menetapkan kebijakan penelitian yang dapat dimanfaatkan dalam pengabdian pada masyarakat.

\section{Pembahasan}

Kebijakan program penelitian dan pengabdian masyarakat yang dilakukan oleh perguruan tinggi baik perguruan tinggi (PT) negeri maupun swasta

Kebijakan program penelitian dan pengabdian masyarakat yang dilakukan oleh perguruan tinggi baik perguruan tinggi (PT) negeri maupun swasta berdasarkan pada kebijakan umum yang ditetapkan oleh Direktorat Pendidikan Tinggi (Dikti) Depdiknas dan kebijakan masing-masing PT. Namun, masih banyak PT yang belum mampu melaksanakan kebijakan tersebut dengan konsekwen. Hal ini disebabkan belum adanya standar mutu penelitian, belum ada payung penelitian yang standar, dan masih kurangnya sosialisasi pelaksanaan program di PT. Namun disadari pula bahwa kebijakan itu kompleks seperti yang dikemukakan oleh Dunn (1981) dalam Dwidjowijoto (2006:x) yang mendefinisikan kebijakan: "policy as complex pattern of independent collective choices, including decision not to act, made by government bodies and officials". Oleh sebab itu, PT menyesuaikan kebijakan tersebut dengan kemampuan dan pandangan masing-masing PT untuk dijadikan standar penelitian. Standar ini berbeda antara PT yang satu dengan yang lainya sehingga penelitianpun berbeda dan kemampuan peneliti dan dosen di masing-masing PT yang sangat bervariasi. Ada PT yang sudah mampu mengikuti standar yang ditetapkan oleh Dikti, namun kebanyakan PT terutama PT swasta banyak yang masih kurang dari standar yang ditetapkan.

Kebijakan umum yang dilakukan oleh kebanyakan PT lebih cenderung mengedepankan pilar peningkatan mutu, relevansi, dan daya saing dibanding dengan pilar lainya karena pilar ini dianggap mampu menarik minat mahasiswa dan menjadi unggulan PT. Kenyataan yang sesunguhnya bahwa masih banyak PT belum mampu melaksanakan janjinya untuk melaksanakan pilar yang mereka jadikan sebagai unggulan terutama PT swasta di berbagai daerah.

Selanjutnya, kebijakan penelitian di PT berdasarkan pada profesionalisme para penelitinya dan mengikuti kaidah metode penelitian keilmuan, etika penelitian sesuai dengan Ethical Peer Reviewer, dan Visi, Misi (Renstra). Demikian halnya program P2M yang 
menjadi unggulan dalam meningkatkan kemampuan dosen dan mahasiswa dalam ilmu pengetahuan dan teknologi baik untuk bahan ajar atau pemanfaatan dalam kegiatan pengabdian masyarakat tidak banyak yang dapat digunakan atau tidak bisa diaplikasikan secara langsung. Kebijakan dan program penelitian tersebut belum bisa diterapkan dalam kegiatan penelitian yang sesungguhnya. Hal ini terlihat dari hasil-hasil penelitian PT yang belum banyak digunakan dalam kegiatan pengabdian masyarakat dan juga dalam pemanfatan untuk peningkatan dan penambahan bahan ajar masih sangat kurangnya yang dipublikasi di jurnal (nasional, internasional), dan perolehan hak paten masih sangat kurang. Dengan demikian dapat dikatakan bahwa hasilhasil penelitian PT belum banyak yang dapat digunakan untuk peningkatan kemampuan masyarakat. Disamping itu, penelitian bukan hanya dilaksanakan oleh lembaga penelitian tapi juga dilaksanakan oleh departemen/jurusan/ prodi dan dosen secara individu dan kelompok termasuk inkubator bisnis. Hal ini menunjukan bahwa PT sudah mulai melaksanakan kerjasama dengan institusi busnis sehingga hasil penelitianpun dapat digunakan oleh lembaga bisnis. Ini juga dapat dikatakan bahwa kebebasan penelitian bukan hanya pada lembaga penelitian yang ada di PT atau individu dan kelompok dosen tapi juga lembaga lainpun sudah bisa memanfaatkan hasil penelitian PT. Kemandirian lembaga penelitian juga sulit dijadikan sebagai satu-satunya lembaga yang berhak meneliti karena ada kebebasan bagi dosen secara individu atau kelompok untuk melakukan penelitian. Akibat dari kebebasan ini, maka hasil-hasil penelitian masih banyak yang tidak terkontrol sehingga mutu penelitian tersebut banyak yang tidak dapat dimanfaatkan dalam kegiatan pengabdian masyarakat.

Implementasi kebijakan penelitian dan pengabdian masyarakat yang dilaksanakan oleh PT negeri dan swasta selama ini dalam meningkatkan kualitas pendidikan tinggi

Pemisahan lembaga penelitian dan lembaga pengabdian masyarakat berdampak pada kurangnya sharing ilmu pengetahuan diantara dosen sehingga kemampuan metodologi penelitian dosen terutama dosen muda tidak berkembang. Akibatnya, program penelitian dan hasil-hasil penelitian banyak yang tidak dapat dimanfaatkan untuk kegiatan pengabdian masyarakat, tidak mampu meningkatkan dan memberi sumbangan peningkatan pengetahuan dan teknologi pada PT dan dosen serta mahasiswa.

Dalam melaksanakan kegiatan penelitian, penelitian-penelitian yang dibiayai oleh Dikti belum bisa diterapkan semua oleh PT karena masingmasing program tersebut mempunyai kendala termasuk kurangnya informasi tentang program yang dibuat oleh Dikti dan kajian akademik PT yang kurang relevan.

Pelaksanaan pengabdian masyarakat yang berkaitan dengan pemanfaatan hasil-hasil penelitian yang dilakukan oleh PT

Program-program penelitian dan pengabdian masyarakat yang telah dibuat dan kebijakan yang ditetapkan baik oleh PT maupun oleh Dikti belum semua dapat dilaksanakan oleh PT. Hal ini terlihat dari hasil penelitian yang menunjukkan bahwa kegiatan pengabdian masyarakat yang dilaksanakan oleh PTN/PTS tidak berdasarkan hasil penelitian. Ini disebabkan oleh program penelitian PT kurang relevan dengan program pengabdian masyarakat. Hal ini tidak sejalan dengan definisi kebijakan menurut Derbyshire dalam Wibawa (1994:49) yang mengatakan bahwa" a set of planned activities aimed at improving social and economical conditions".

Drew (1980 dalam Bell (1993:2) menyarankan untuk melakkan penelitian seperti yang dikatakannya "research is conducted to solve problems and to expand knowledge and he stresses that research is a systematic way of asking questions, a systematic method of enquiry".

Disamping itu, PT sering terlambat menyelesaikan penelitian dalam jangka waktu yang ditetapkan, kurangnya biaya dan sarana/ prasarana, dan kurangnya penelitian PT yang berdasarkan kebutuhan masyarakat. Kendala lain adalah kekurangan sumber daya peneliti/dosen yang berkualitas dan mampu melaksanakan penelitian serta mempunyai dedikasi dalam melaksanakan pengabdian masyarakat. Disamping itu, dosenpun lebih banyak menghabiskan waktunya untuk mengajar dan kurang 
berminat melaksanakan penelitian dan pengabdian masyarakat.

Untuk meningkatkan kualitas pengabdian masyarakat agar mampu meningkatkan kesejahteraan masyarakat, maka PT perlu melakukan langkah-langkah 1) melaksanakan studi kelayakan, 2) menerapkan hasil penelitian, 3) menambah dana pengabdian pada masyarakat, 4) pengembangan metodologi Participaty Active Reseacrh $(P A R), 5)$ relevansi penelitian dan kebutuhan masyarakat, 6) meningkatkan IPTEK bagi masyarakat, 7) membuat penelitian terapan dan penelitian tepat guna, dan mendorong masyarakat untuk menykai Iptek Selanjutnya, peningkatan mutu pengabdian pada masyarakat yang sebaiknya dilakukan oleh PT melalui kerjasama dengan masyarakat merupakan langkah tepat untuk melihat kebutuhan masyarakat yang akan dibantu sehingga pelaksanaan pengabdian masyarakat berdampak pada peningkatan kesejahteraan masyarakat di tempat pelaksanaan penelitian dan pengadian masyarakat.

Pemanfaatan hasil-hasil penelitian dan pengembangan yang dilakukan oleh PT untuk peningkatan keilmuan dan/atau ilmu pengetahuan dan teknologi terutama dalam kegiatan perekayasaan, inovasi, dan difusi teknologi

Hasil-hasil penelitian yang dilakukan oleh PTN/PTS untuk pengembangan dan peningkatan ilmu pengetahuan secara umum dapat dimanfaatkan untuk pengembangan dan peningkatan ilmu pengetahuan serta kemampuan dosen.

Namun perlu dukungan berbagai unsur politik, ekonomi, dan sosial. Berkaitan dengan road map penelitian yang ada di PT, sebagian PT belum mampu membuat rencana strategis PT dalam bidang penelitian baik rencana jangka pendek maupun rencana jangka menengah. Hal ini akan berdampak pada kegiatan penelitian yang hanya dilakukan sesuai dengan kebutuhan sesaat dan belum mampu merencanakan penelitian yang dibutuhkan baik oleh PT maupun oleh masyarakat dalam jangka waktu tertentu. Selain itu, program penelitian di PT hanya berdasarkan pada kegiatan yang disuguhkan oleh Dikti atau Depdiknas dan belum mampu memprediksi masalah yang akan diteliti dalam jangka waktu tertentu dan yang mampu meningkatkan ilmu pengetahuan dan teknologi serta bermanfaat bagi masyarakat.

\section{Simpulan dan Saran}

\section{Simpulan}

Berdasarkan temuan penelitian dapat disimpulkan bahwa kebijakan program penelitian dan pengabdian masyarakat yang dilakukan oleh perguruan tinggi (PT) baik negeri maupun swasta berdasarkan pada kebijakan umum yang ditetapkan oleh Direktorat Pendidikan Tinggi (Dikti) Depdiknas dan kebijakan masing-masing PT. Namun, masih banyak PT yang belum mampu melaksanakan kebijakan tersebut dengan konsekwen. Beberapa PT menyesuaikan kebijakan Dikti tersebut dengan kondisi masingmasing PT kebijakan untuk melibatkan lembaga/ individu pelaksana penelitian seperti lembaga penelitian, departemen/jurusan/prodi, dosen secara individu atau kelompok.

Implementasi kebijakan penelitian dan pengabdian masyarakat yang dilaksanakan oleh PT negeri dan swasta selama ini dalam meningkatkan kualitas pendidikan tinggi masih menghadapi kendala antara lain 1) lembaga penelitian dan pengabdian masyarakat masih terpisah, 2) sosialisasi P2M masih kurang, 3) kemampuan metodologi penelitian dosen masih rendah. Sementara itu, untuk meningkatkan mutu pengabdian pada masyarakat, PT bekerja sama dengan masyarakat tempat pengabdian masyarakat dilaksanakan, melakukan penelitian yang relevan dengan kebutuhan masyarakat, 4) meningkatkan IPTEK bagi masyarakat, 5) membuat penelitian terapan dan penelitian tepat guna, dan 6) meningkatkan minat masyarakat terhadap Iptek.

Hasil-hasil penelitian dan pengembangan yang dilakukan oleh PT secara umum dapat dimanfaatkan untuk peningkatan keilmuan dan/ atau ilmu pengetahuan dan teknologi terutama dalam kegiatan perekayasaan, inovasi serta difusi teknologi. Namun, masih sedikit yang dapat digunakan untuk meningkatkan jumlah materi ajar, publikasi nasional/ internasional, dan perolehan hak paten.

Pelaksanaan pengabdian masyarakat yang berkaitan dengan pemanfaatan hasil-hasil penelitian yang dilakukan oleh PT adalah 
kebanyakan PT melaksanakan pendidikan dan pelatihan masyarakat, pelayanan masyarakat, serta kaji tindak dari Iptek yang dihasilkanya. Namun, pemanfaatan hasil penelitian untuk melaksanakan kegiatan-kegiatan tersebut masih sangat kurang. Manfaat kegiatan yang dilakukan oleh PT dalam melaksanakan pengabdian masyarakat lebih banyak berorientasi pada pelatihan mahasiswa dalam meningkatkan kemampuan, kemandirian, dan kepedulian mahasiwa terhadap persoalan masyarakat. Kendala yang dihadapi dalam pelaksanaan pengabdian masyarakat, antara lain hasil penelitian PT belum bisa diterapkan sepenuhnya karena hasil penelitian belum memberikan solusi yang jelas mengenai masalah yang dihadapi masyarakat dan biaya yang terbatas.

\section{Saran}

Saran yang akan disampaikan berikut ini berdasarkan kesimpulan penelitian yang dikemukakan di atas.

Depdiknas (Dikti): 1) Dikti perlu menyebarluaskan informasi program penelitian dan pengabdian masyarakat bukan hanya melalui surat ke PTN/PTS dan PTAI tapi juga melalui sosialisasi dengan jaringan penelitian dan internet ke PT terutama PT swasta, 2) Dikti perlu membantu PT terutama dosen untuk meningkatkan kemampuanya dengan memberikan kesempatan yang seluas-luasnya bagi dosen untuk melanjutkan pendidikan, mengikuti seminar, workshop, melakukan penelitian dan pengabdian masyarakat, dan membuat program magang penelitian bagi dosen, 3) Dikti meningkatkan pemantauan dan monitoring mengenai pelaksanaan kebijakan dan program PT yang dikeluarkan agar pelaksanaanya sesuai dengan tujuan kebijakan, 4) Dikti perlu membuat program dan skema PPM yangg baru sesuai dengan kebutuhan masyarakat dan industri dan P2M Dikti perlu memetakan unggulan lokal yang harus dilakukan oleh PT, dan 5) Dikti perlu melakukan koordinasi antar lembaga peneliti seperti Lipi, BPPT, Kementerian Ristek, LPND, dan Departemen terkait, lembaga riset swasta, dan industri baik dalam pendanaan maupun dalam membuat road map riset dan database sehingga tidak tumpang tindih.
Purguruan Tinggi (PT): 1) PT perlu meningkatkan kemampuan peneliti dan dosen dengan cara memberikan kesempatan pada dosen untuk meneliti dan melakukan kegiatan pengabdian pada masyarakat. Oleh sebab itu, perlu ada kabijakan ketersediaan proporsi waktu meneliti bagi dosen dan mengurangi beban mengajar bagi dosen, tidak melibatkan dosen secara rutin pada pekerjaan administrasi. Selanjutnya, PT melakukan pembinaan dan pemberian insentif dan reward pada setiap dosen yang melakukan penelitian. Untuk kenaikan pangkat dosen persyaratan pengabdian kepada masyarakat minimal satu dan melaksanakan penelitian berbasis skill, 2) PT harus membuat kebijakan standar dan kriteria penelitian yang tepat yang harus diikuti oleh semua peneliti baik lembaga penelitian maupun dosen secara individu atau kelompok, 3) PT perlu konsekwen melaksanakan kebijakan penelitian yang telah ditetapkan agar penelitian lebih terarah dan menghasilkan penelitian yang bermanfaat untuk peningkatan ilmu pengetauan dan teknologi serta penerapanya dalam kegiatan pengabdian masyarakat yang lebih aplikatif. Oleh sebab itu, PT perlu membuat daerah/industri kecil binaan agar hasil penelitian dan pengabdian masyarakat lebih nyata sebagai implementasi Tridharama PT, 4) PT perlu bekerjasama dengan masyarakat dalam merencanakan, mengimplementasikan, menilai hasil penelitian, dan melaksanakan monitoring kegiatan pengabdian masyarakat. Disamping itu, PT perlu mencari dukungan dan bekerjasama dengan pihak lain termasuk unsur politik, ekonomi, sosial. Kerjasama dengan pemerintah daerah (Provinsi dan Kabupaten/Kota) untuk mensosialisasikan hasil-hasil penelitian dan pengabdian masyarakat termasuk sumber daya yang dimiliki oleh PT. Hal ini perlu agar pemerintah daerah dapat memilih dan memanfaatkan hasilhasil penelitian PT. Selanjutnya, PT juga perlu menawarkan program penelitian yang bisa dimanfaatkan langsung oleh Pemda, 5) PT perlu membuat program penelitian jangka menengah dan jangka panjang (road map) penelitian dan bekerjasama dengan stakeholder dalam penelitian dan pengabdian masyarakat, 6) PT perlu melaksanakan sosialisasi semua bentuk penelitian dengan memperbanyak workshop penulisan proposal penelitian dan lebih ditekankan 
pada tingkat jurusan. Disamping itu, PT perlu meningkatkan anggaran penelitian dan pengabdian masyarakat dengan bekerjasama atau melalui alokasi dana dari pemerintah (Dikti, Pemda, dan PT), dan 7) PT perlu membuat kebijakan penelitian bagi dosen untuk mengembangkan ilmu pengetahuan dan hasilnya dapat digunakan sebagai bahan ajar mata kuliah yang diajarkan. Dengan demikian hasil-hasil penelitian bukan sekedar laporan ke universitas atau untuk menambah kredit, tapi dimanfaatkan sebagai bahan ajar atau penemuan ilmu baru untuk pengembangan keilmuan yang dapat dimanfaatkan oleh masyarakat.

Lembaga Lain: Dalam melaksanakan dan memanfaatkan hasil penelitian PT, lembaga lain (inkubator bisnis) disarankan untuk mengikuti standar penelitian yang ditetapkan PT dan bekerjasama dengan PT.

\section{Pustaka Acuan}

Arikunto, Suharsimi. 2000. Manajemen Penelitian, Jakarta: PT. Asdi Mahasatya.

Bell, Judith. 1993. Doing Your Research Project. A Guide for first-time researchers in education and social science. Open University Press. Buckingham.

Danim, Sudarwan. 2005. Pengantar Studi Penelitian Kebijakan, Jakarta. Bumi Akasara.

Departemen Pendidikan Nasional Undang-Undang No. 20/2003 Tentang Sistem Pendidikan Nasional.

--- - Rencana Strategis (RENSTRA) Depdiknas Tahun 2005-2009, Jakarta: Depdiknas.

-_-_- Buku Panduan Pengelolaan Program Hibah DP2M Ditjen Dikti - Edisi VII Jakarta, 2006.

-_-_- Buku Panduan Pengelolaan Program Hibah DP2M Ditjen Dikti - Edisi VIII Jakarta, 2008.

- - - - Kegiatan Penelitian Fundamental, Riset Andalan Perguruan Tinggi Dan Industri, Direktorat Jenderal Pendidikan Tinggi Depdiknas (2004).

Dwidjowijoto, R. Nugroho. 2006. Analisis Kebijakan. PT. Elex Media Komputindo, Jakarta.

Emzir. 1995. Studi Evaluasi Buku Teks Dalam pengajaran Bahasa Arab (Laporan Studi), Jakarta: Fakultas Pendidikan Bahasa dan Seni IKIP Jakarta.

Griffin, Ricky W. 1987. Management, USA: USA Houghton Miffin Company.

http://www.fao.org/Wairdocs/TAC/X5792E/x5792e09.htm.

Majchrzak, Ann. Methods for Policy Research, New Delhi: Applied Social Research Series, 1984, Vol 3.

Moleong, Lexi. J. 2000. Metodologi Penelitian Kualitatif, Bandung: PT. Remaja Rosdakarya.

Mondy, R. Wayne and Shane R. Premeoux. 1993.Management. Massachussets. Allyn and Baco.

Peraturan Presiden No. 7 Tahun 2005 tentang Rencana Pembangunan Jangka Menengah (20052009) Bidang Pendidikan.

Strauss, Anselm and Corbin, Juliet. 1990. Basic Qualitative Research. Grounded Theory, Procedures and Techniques, London: Sage Publications, Inc.

Wibawa, Samodra. 1994. Kebijakan Publik: Proses dan Analisis. Jakarta: Intermedia. 